\title{
COVID-19: consequences for mental health and the use of e-Mental health options
}

\author{
COVID-19: последствия для психического здоровья и возможности \\ применения электронных технологий при оказании помощи
}

DOI: 10.17650/2712-7672-2020-1-1-3-7

\author{
Wolfgang Gaebel ${ }^{1,2,3}$, Rabea Lukies ${ }^{3}$, \\ Johannes Stricker ${ }^{1,2}$ \\ ${ }^{1}$ Department of Psychiatry, Medical Faculty, LVR-Klinikum \\ Düsseldorf, Heinrich-Heine-University, Düsseldorf, Germany; \\ ${ }^{2}$ WHO Collaborating Centre for Quality Assurance and \\ Empowerment in Mental Health, Düsseldorf, Germany; \\ ${ }^{3}$ LVR-Institute for Healthcare Research, Cologne, Germany.
}

\author{
Вольфганг Гебель ${ }^{1,2,3}$, Рабеа Лукис ${ }^{3}$, \\ Йоханнес Стрикер ${ }^{1,2}$ \\ ${ }^{1}$ Кафедра психиатрии медицинского факультета \\ Университета им. Генриха Гейне, Психиатрическая \\ больница, Дюссельдорф, Германия; ${ }^{2}$ Коллаборационный \\ чентр ВОЗ по контролю качества и определению \\ полномочий в области охраны психического здоровья, \\ Дюссельдорф, Германия; 'Институт медицинских \\ исследований в области психиатрии, Кельн, Германия.
}

\begin{abstract}
The current COVID-19 pandemic is associated with fear, insecurity, and perceived social isolation worldwide. In this editorial, we discuss the influence of the COVID-19 pandemic on mental health among the general population and among particularly vulnerable groups (e.g., people with pre-existing mental illness). Additionally, we explore the role of e-mental health options in times of social distancing. Preliminary empirical evidence indicates that a wide range of people have experienced mental health difficulties due to the COVID-19 pandemic and corresponding infection-control measures. E-mental health options are a feasible means of addressing psychological distress and mental illness during the pandemic. Thus, these options should be made available in a timely fashion. Future multidisciplinary research is needed to develop e-mental health strategies that specifically focus on the consequences of social isolation, economic hardship and fear of infection.
\end{abstract}

\section{АННОТАЦИЯ}

Текущая пандемия COVID-19 во всем мире сопровождается страхом, чувством небезопасности и ощущением социальной изоляции. В данной редакционной статье мы обсуждаем влияние пандемии COVID-19 на психическое здоровье населения и отдельныхуязвимых групп (например, людей, уже имеющих психические заболевания). Кроме того, мы исследуем возможности применения электронных технологий при оказании помощи в период социального дистанцирования. Предварительные данные эмпирических исследований указывают на то, чтоуширокого круга людей возникали проблемы с психическим здоровьем из-за пандемии COVID-19 и в связи с применением мер по контролю инфекции. Использование электронных технологий в период пандемии является целесообразным способом оказания помощи в отношении психического здоровья. В связи с этим необходимо обеспечить своевременную доступность дистанционного оказания помощи. Необходимы также дальнейшие междисциплинарные исследования для разработки стратегий использования электронных технологий в охране психического здоровья, сфокусированные на последствиях социальной изоляции, экономических трудностей и страха перед инфекцией.

Keywords: e-mental health, mental health, COVID-19, pandemic

Ключевые слова: электронные технологии охраны психического здоровья, психическое здоровье, COVID-19, пандемия 


\section{INTRODUCTION}

The current COVID-19 pandemic has caused insecurity and fear around the globe. Additionally, measures such as social distancing and home confinement, which help prevent the spread of the disease, carry the risk of increasing psychological distress or aggravation of preexisting mental illness. Thus, mental health experts worldwide have raised concerns over the consequences of the COVID-19 pandemic for mental health (e.g., [14]). These concerns are in line with previous evidence relating to mental health problems following isolation measures in the context of contagious diseases [5]. There is also some preliminary evidence indicating the negative effects of the current COVID-19 pandemic on mental health with stricter and more efficient social distancing measures (e.g., quarantine), potentially causing more severe consequences $[2,6]$.

The World Health Organization (WHO), the InterAgency Standing Committee (IASC) created by the United Nations (UN), the World Psychiatric Association (WPA), and several other organizations have published guidelines and resources for maintaining or restoring mental health during the pandemic [7-9]. Additionally, national organizations are setting up tailored national strategies to respond to mental health issues during the pandemic. Many of these strategies include onlinebased mental health options (e.g., [1, 10, 11]), which is partly due to difficulties associated with inpatient mental health services (e.g., the risk of infections; [12]). In this editorial, we discuss evidence for the impact of the current COVID-19 pandemic on mental health among the general population and among vulnerable groups (e.g., persons with pre-existing mental illness). Additionally, we explore how the use of e-mental health options can help maintain or restore mental health in the current COVID-19 pandemic.

\section{CONSEQUENCES OF THE COVID-19 PANDEMIC FOR MENTAL HEALTH}

The COVID-19 pandemic may negatively influence mental health via increased stress levels due to fears about infection, economic hardship, job loss or via perceived social isolation as a consequence of social distancing measures. Additionally, excessive fear and panic due to misinformation on social media (the socalled "infodemic") may occur [13], which has been termed "coronaphobia" [14]. According to a recent review based on 28 primary articles (including four empirical studies), anxiety and depressive symptoms have been common during the COVID-19 pandemic among the general population (16-28\% point prevalence; [15]). There is also some anecdotal evidence of suicides because of fears related to the COVID-19 pandemic [16]. Similarly, anecdotal evidence from Germany indicates the occurrence of specific symptom clusters, such as a nihilistic "apocalyptic" syndrome among elderly patients who have been cut off from their families during the pandemic [17].

Some societal groups may be particularly vulnerable to the psychological consequences of the COVID-19 pandemic. As stress increases the risk of relapse or aggravation of pre-existing mental illness, persons with pre-existing mental illness may be particularly prone to experiencing difficulties $[12,18]$. Additionally, persons with mental illness may avoid inpatient or outpatient services due to fear of infection during the pandemic. Similarly, infection-control measures (e.g., travel restrictions) may complicate regular outpatient visits. Other potentially vulnerable groups include healthcare workers (e.g., [3]), older persons (e.g., [19]), students studying overseas (e.g., [20]), homeless persons [21] and migrant workers [22]. For example, in a recent study of Chinese medical staff during the COVID-19 outbreak, $50.7 \%$ of the participating medical staff reported depressive symptoms; $44.7 \%$ reported anxiety symptoms; $36.1 \%$ reported symptoms of insomnia and 73.4\% reported general stress-related symptoms [23].

For certain groups, living circumstances can also influence the degree to which persons experience mental health difficulties during the COVID-19 pandemic. In a study of college students in China [24] who were living in urban areas (as opposed to rural areas), the stability of a student's family income and living with parents were found to be protective factors against anxiety during the pandemic. Results indicated that stressors related to anxiety levels included worry about economic influences, worry about academic delays and the influence on daily life, whereas social support could have a buffering effect [24]. An innovative study applying machine learning algorithms to postings on social media found that social media users in China more frequently posted about negative emotions (e.g., anxiety, depression and indignation) after the COVID-19 outbreak, compared to before [25]. 
In sum, there is preliminary evidence of substantial negative effects of the COVID-19 pandemic on mental health. As more people have been affected by COVID-19 compared to previous pandemics (e.g., SARS or H1N1 influenza), the challenges for mental healthcare seem unprecedentedly large. Against this background, with such severe consequences resulting from the COVID-19 pandemic in terms of mental health, it becomes clear that sustainable solutions are needed to address psychological distress and mental illness in the current situation.

\section{THE USE OF E-MENTAL HEALTH OPTIONS IN THE COVID-19 PANDEMIC}

Various stakeholders have recommended the use of e-mental health options as a means of addressing the negative impacts of the COVID-19 pandemic on mental health (e.g., $[4,26])$. Some of these recommendations cover mental health options that are adequate for persons with and without pre-existing mental illness. Such options include, for example, the use of online materials for education in mental health (e.g., [23]) or applications covering self-help (e.g., [27]). Other recommendations, such as synchronous telemedicine in mental healthcare for diagnosis and counselling (e.g., [26]) and asynchronous therapeutic intervention such as structured letter therapy (e.g., [28]), are tailored for persons with mental illness. Growing evidence shows the general effectiveness of digital solutions for improving mental health (e.g., [29, 30]). A recent review also showed that e-mental health interventions may be effective in crisis settings [31].

The COVID-19 pandemic may be a "turning point" for e-mental health, which may durably increase the uptake of e-mental health options [27]. In China (the first country to be affected by the pandemic), online mental health options (e.g., online mental health education, online psychological counselling and online psychological selfhelp intervention systems services) have been widely used during the pandemic [23]. However, to date, many countries are not yet in a position to support the use of e-mental health solutions during the pandemic. In Germany, just this year, the Digital Health Care Act has come into effect, enabling the prescription of medical apps. A consistent digital infrastructure throughout healthcare institutions is still lacking. Recently, however, in response to the COVID-19 outbreak, the National Association of Statutory Health Insurance Physicians and the Association of Statutory Health Insurances have agreed to expand the reimbursement possibilities for video consultations [32]. Thus, the pandemic seems to have accelerated the regulatory processes required for the use of e-mental health services.

National governments, health policymakers and crisis policies should consider further accelerating the implementation of e-mental health in order to prevent or reduce psychological distress among the general population and to restore mental health in persons with pre-existing mental illness. As a quick emergency response, governments could expand the legal framework that allows the application and reimbursement of e-mental health products and publish guidance for their use. However, for an increased uptake in the long run, more sustainable policy measures must be introduced, including development of adequate financing strategies, the funding of further research, promotion of high standards of usability and interoperability, and quality control for e-mental health products on the market [33,34].

In sum, e-mental health options should quickly be made available to all persons potentially suffering from the psychological consequences of the COVID-19 pandemic, particularly to vulnerable groups, such as persons with pre-existing mental illness, healthcare professionals and older people. Future multidisciplinary research is needed to develop e-mental health strategies that specifically focus on the consequences of social isolation, economic hardship and fear of infection (see also [35]).

Author contributions: Rabea Lukies and Johannes Stricker contributed equally to researching literature and writing the manuscript. Prof. Dr. Wolfgang Gaebel provided ideas about content and literature, and critically revised the draft manuscript.

Funding: Prof. Dr. Wolfgang Gaebel and Rabea Lukies are part of the eMEN project cited in the manuscript, which received funding from theEuropeanUnion'sInterregNorthWest-Europe programme.

Conflict of interest:The authors declare that they have no conflicts of interest.

Correspondence to:

Prof. Dr. Wolfgang Gaebel

wolfgang.gaebel@uni-duesseldorf.de 


\section{References}

1. Li W, Yang Y, Liu ZH, Zhao YJ, Zhang Q, Zhang L, Cheung T, Xiang YT. Progression of Mental Health Services during the COVID-19 Outbreak in China. Int J Biol Sci. 2020 Mar 15;16(10):1732-1738. doi: 10.7150/ ijbs.45120. PMID: 32226291; PMCID: PMC7098037.

2. Lima CKT, Carvalho PMM, Lima IAAS, Nunes JVAO, Saraiva JS, de Souza RI, da Silva CGL, Neto MLR. The emotional impact of Coronavirus 2019-nCoV (new Coronavirus disease). Psychiatry Res. 2020 May;287:112915. doi: 10.1016/j.psychres.2020.112915. Epub 2020 Mar 12. PMID: $32199182 ;$ PMCID: PMC7195292.

3. Sani G, Janiri D, Di Nicola M, Janiri L, Ferretti S, Chieffo D. Mental health during and after the COVID-19 emergency in Italy. Psychiatry Clin Neurosci. 2020 Jun;74(6):372. doi: 10.1111/pcn.13004. Epub 2020 Apr 24. PMID: 32248608.

4. Xiang YT, Yang Y, Li W, Zhang L, Zhang Q, Cheung T, Ng CH. Timely mental health care for the 2019 novel coronavirus outbreak is urgently needed. Lancet Psychiatry. 2020 Mar;7(3):228229. doi: 10.1016/S2215-0366(20)30046-8. Epub 2020 Feb 4. PMID: 32032543; PMCID: PMC7128153.

5. Brooks SK, Webster RK, Smith LE, Woodland L, Wessely S, Greenberg N, Rubin GJ. The psychological impact of quarantine and how to reduce it: rapid review of the evidence. Lancet. $2020 \mathrm{Mar}$ 14;395(10227):912-920. doi: 10.1016/S0140-6736(20)30460-8. Epub 2020 Feb 26. PMID: 32112714; PMCID: PMC7158942.

6. Rubin GJ, Wessely S. The psychological effects of quarantining a city. BMJ. 2020 Jan 28;368:m313. doi: 10.1136/bmj.m313. PMID: 31992552.

7. World Health Organization (WHO) [Internet]. Mental health and psychosocial considerations during the COVID-19 outbreak. 2020 [cited 22 April 2020]; Available from: https://www.who.int/ docs/default-source/coronaviruse/mental-health-considerations. pdf?sfvrsn=6d3578af_8\&ua=1

8. IASC (Inter-Agency Standing Committee) [Internet]. Briefing note on addressing mental health and psychosocial aspects of COVID-19 outbreak version 1.1. 2020 [cited 22 April 2020]; Available from:https://interagencystandingcommittee.org/ system/files/2020-03/MHPSS\%20COVID19\%20Briefing\%20 Note\%202\%20March\%202020-English.pdf

9. World Psychiatric Association (WPA) [Internet]. Coronavirus (COVID-19) mental health resources. 2020 [cited 22 April 2020]; Available from: https://www.wpanet.org/covid-19-resources

10. Deutsche Gesellschaft für Psychologie (DGPs) [Internet]. Empfehlungen zur Durchführung Videokonferenz-basierter Psychotherapie [Recommendations for the implementation of video conference-based psychotherapy]. 2020 [cited 22 April 2020]; Available from: https://lppkjp.de/wp-content/ uploads/2020/03/EmpfehlungenVideobasierte-Psychotherapie_ DGPs_IG-E-Health_20200326.pdf

11. Jung SJ, Jun JY. Mental Health and Psychological Intervention Amid COVID-19 Outbreak: Perspectives from South Korea. Yonsei Med J. 2020 Apr;61(4):271-272. doi: 10.3349/ymj.2020.61.4.271. PMID: 32233168; PMCID: PMC7105405.

12. Zhu Y, Chen L, Ji H, Xi M, Fang Y, Li Y. The Risk and Prevention of Novel Coronavirus Pneumonia Infections Among Inpatients in Psychiatric Hospitals. Neurosci Bull. 2020;36(3):299-302. doi:10.1007/s12264-020-00476-9

13. The Lancet. COVID-19: fighting panic with information. Lancet. 2020 Feb 22;395(10224):537. doi: 10.1016/S0140-6736(20)303792. PMID: 32087777; PMCID: PMC7138040.

14. Asmundson GJG, Taylor S. Coronaphobia: Fear and the 2019-nCoV outbreak. J Anxiety Disord. 2020 Mar;70:102196. doi: 10.1016/j. janxdis.2020.102196. Epub 2020 Feb 10. PMID: 32078967; PMCID: PMC7134790.

15. Rajkumar RP. COVID-19 and mental health: A review of the existing literature. Asian J Psychiatr. 2020 Apr 10;52:102066. doi: 10.1016/j.ajp.2020.102066. Epub ahead of print. PMID: 32302935; PMCID: PMC7151415.

16. Mamun MA, Griffiths MD. First COVID-19 suicide case in Bangladesh due to fear of COVID-19 and xenophobia: Possible suicide prevention strategies. Asian J Psychiatr. 2020 Apr 7;51:102073. doi: 10.1016/j.ajp.2020.102073. Epub ahead of print. PMID: 32278889; PMCID: PMC7139250.

17. Fatke B, Hölzle P, Frank A, Förstl H. Psychische Probleme in der Pandemie - Beobachtungen während der COVID-19-Krise [COVID-19 Crisis: Early Observations on a Pandemic's Psychiatric Problems]. Dtsch Med Wochenschr. 2020 May; 145(10):675-681. German. doi: 10.1055/a-1147-2889. Epub 2020 Apr 9. PMID: 32274787.

18. Yao H, Chen JH, Xu YF. Patients with mental health disorders in the COVID-19 epidemic. Lancet Psychiatry. 2020 Apr;7(4):e21. doi: 10.1016/S2215-0366(20)30090-0. PMID: 32199510; PMCID: PMC7269717.

19. Yang Y, Li W, Zhang Q, Zhang L, Cheung T, Xiang YT. Mental health services for older adults in China during the COVID-19 outbreak. Lancet Psychiatry. 2020 Apr;7(4):e19. doi: 10.1016/ S2215-0366(20)30079-1. Epub 2020 Feb 19. PMID: 32085843; PMCID: PMC7128970.

20. Zhai $Y$, Du X. Mental health care for international Chinese students affected by the COVID-19 outbreak. Lancet Psychiatry. 2020 Apr;7(4):e22. doi: 10.1016/S2215-0366(20)30089-4. PMID: 32199511; PMCID: PMC7103995.

21. Tsai J, Wilson M. COVID-19: a potential public health problem for homeless populations. Lancet Public Health. 2020 Apr;5(4):e186-e187. doi: 10.1016/S2468-2667(20)30053-0. Epub 2020 Mar 11. PMID: 32171054; PMCID: PMC7104053.

22. Liem A, Wang C, Wariyanti Y, Latkin CA, Hall BJ. The neglected health of international migrant workers in the COVID-19 epidemic. Lancet Psychiatry. 2020 Apr;7(4):e20. doi: 10.1016/S2215-0366(20)30076-6. Epub 2020 Feb 19. PMID: 32085842; PMCID: PMC7129812.

23. Liu S, Yang L, Zhang C, Xiang YT, Liu Z, Hu S, Zhang B. Online mental health services in China during the COVID-19 outbreak. Lancet Psychiatry. 2020 Apr;7(4):e17-e18. doi: 10.1016/S2215-0366(20)300778. Epub 2020 Feb 19. PMID: 32085841; PMCID: PMC7129099.

24. Cao W, Fang Z, Hou G, Han M, Xu X, Dong J, Zheng J. The psychological impact of the COVID-19 epidemic on college students in China. Psychiatry Res. 2020 May;287:112934. doi: 10.1016/j. psychres.2020.112934. Epub 2020 Mar 20. PMID: 32229390; PMCID: PMC7102633.

25. Li S, Wang Y, Xue J, Zhao N, Zhu T. The Impact of COVID-19 Epidemic Declaration on Psychological Consequences: A Study on Active Weibo Users. Int J Environ Res Public Health. 2020 Mar 19;17(6):2032. doi: 10.3390/ijerph17062032. PMID: 32204411; PMCID: PMC7143846.

26. Zhou X, Snoswell CL, Harding LE, Bambling M, Edirippulige S, Bai $X$, Smith AC. The Role of Telehealth in Reducing the Mental Health Burden from COVID-19. Telemed J E Health. 2020 Apr;26(4):377-379. doi: 10.1089/tmj.2020.0068. Epub 2020 Mar 23. PMID: 32202977.

27. Wind TR, Rijkeboer M, Andersson G, Riper H. The COVID-19 pandemic: The 'black swan' for mental health care and a turning point for e-health. Internet Interv. 2020 Apr;20:100317. doi: 10.1016/j.invent.2020.100317. Epub 2020 Mar 19. PMID: 32289019; PMCID: PMC7104190.

28. Xiao C. A Novel Approach of Consultation on 2019 Novel Coronavirus (COVID-19)-Related Psychological and Mental Problems: Structured 
Letter Therapy. Psychiatry Investig. 2020 Feb;17(2):175-176. doi: 10.30773/pi.2020.0047. Epub 2020 Feb 25. PMID: 32093461; PMCID: PMC7047000.

29. Berryhill MB, Culmer N, Williams N, Halli-Tierney A, Betancourt A, Roberts H, King M. Videoconferencing Psychotherapy and Depression: A Systematic Review. Telemed J E Health. 2019 Jun;25(6):435-446. doi: 10.1089/tmj.2018.0058. Epub 2018 Jul 26. PMID: 30048211.

30. Carlbring P, Andersson G, Cuijpers P, Riper H, Hedman-Lagerlöf E. Internet-based vs. face-to-face cognitive behavior therapy for psychiatric and somatic disorders: an updated systematic review and meta-analysis. Cogn Behav Ther. 2018 Jan;47(1):118. doi: 10.1080/16506073.2017.1401115. Epub 2017 Dec 7. PMID: 29215315.

31. Reinhardt I, Gouzoulis-Mayfrank E, Zielasek J. Use of Telepsychiatry in Emergency and Crisis Intervention: Current Evidence. Curr Psychiatry Rep. 2019 Jul 1;21(8):63. doi: 10.1007/s11920-019-1054-8. PMID: 31263972.

32. Kassenärztliche Bundesvereinigung (KBV) [Internet]. Coronavirus: Videosprechstunden unbegrenzt möglich [No limit to video consultation]. 2020 [cited 22 April 2020]; Available from: https://www.kbv.de/html/1150_44943.php
33. Gaebel W, et al. Transnational policy for e-mental health: A guidance document for European policymakers and stakeholders [Internet]. Co-funded by the EU Interreg North-West-Europe programme. 2020, LVR-Institute for Healthcare Research: Düsseldorf/ Köln [cited 22 April 2020]; Available from: https://www.nweurope. eu/projects/project-search/e-mental-health-innovation-andtransnational-implementation-platform-north-west-europe-emen/ news-blogs/transnational-policy-for-e-mental-health-a-guidancedocument-for-european-policymakers-and-stakeholders/

34. Gaebel W, Lukies R, Kerst A, et al. Upscaling e-mental health in Europe: a six-country qualitative analysis and policy recommendations from the eMEN project [published online ahead of print, 2020 May 11]. Eur Arch Psychiatry Clin Neurosci. 2020;10.1007/ s00406-020-01133-y. doi:10.1007/s00406-020-01133-y

35. Holmes EA, O'Connor RC, Perry VH, Tracey I, Wessely S, Arseneault L, Ballard C, Christensen H, Cohen Silver R, Everall I, Ford T, John A, Kabir T, King K, Madan I, Michie S, Przybylski AK, Shafran R, Sweeney A, Worthman CM, Yardley L, Cowan K, Cope C, Hotopf M, Bullmore E. Multidisciplinary research priorities for the COVID-19 pandemic: a call for action for mental health science. Lancet Psychiatry. 2020 Jun;7(6):547-560. doi: 10.1016/S2215-0366(20)30168-1. Epub 2020 Apr 15. PMID: 32304649; PMCID: PMC7159850. 